医学図書館 $31(4) ： 386-390,1984$

\title{
パソコンの基礎的知識（1）
}

\section{Basic Knowledge of Personal Computer (1)}

清 水悟*

東京女子医科大学衛生学教室

情報化社会の日常語として, マイコン, パソコン, ワープロ……等の言葉が身のまわりに市民権を得たこ とは否定する余地もなくなり，より一層汇濫の兆が見 える。数十年前, テレビが日本人の生活に浸透したよ jに……それは，テレビが家庭を主な培地にしたの と違い, 職場を中心に増殖して来た。時あたかも，高 度経済成長から省工ネ, 省力化の時代へと移行する時 期であった。

職場で最も影響を受けたのは，新たな勉強をせまら れた中堅クラス(中高年者)である。新しいものを吸収 する時の学習曲線は年齢に比例することは言うまでも ない。ただ, パソコンの值段等の要素から神格化して, 手を触れるのを恐がったりする。万能などという迷信 をすてて, あくまでも道具であることから気楽に親し む態度が必要であると思える。

そこで, 気楽に触れる為の知識, (中には不必要なも のもあるが)について, 筆者の浅学の中から述べること によって，文責の任を終えることにする。

\section{I . 雑学として}

古来，数の表現には，石を使ったり，その石の置き 方，あるいは小枝など様々なものを工夫してきた。特 に興味を持つのは縄を用いて結び目の数で “数值”を 表現したことである。とにかく, 種々様々なもので数 のみならず,「種々の情報」を表現したに違いない。あ る種の “計算機”というより，言葉を含めた “情報記

\footnotetext{
* Satoru SHIMIZU : Tokyo Women's Medical College, Department of Hygiene.

(昭和 59 年 11 月 15 日 受理)
}

憶装置”という観がある。

さて，昔からの計算機といえば “ソロバン゙である。 今の “ソロバン”は, ひと桁の列に 5 という数值のカ テゴリーを表わす珠が一つ, 1 という数值のカテゴリー を表わす珠が四つあるが，その昔の算盤には 5 を表わ すものが 2 コ，1を表わすものが 5 コあった。図1の 様に, 使用方法についてはよく知らないが, 多分今日我々 が, 買い物をして代金を払う時, 3,000 円の代金を一万 円で清算する時に，まず一万円札を千円札 10 枚に"く ずじその 10 枚から 3 枚とって残りを返すという様な 置数を目的とする操作をとったのではないかと想像す る。つまり, 算盤の機能を置数を目的としている為, 現在のように 1 桁で 0 〜 9 までを表わすのではなく, 上の桁の 1 に対応する 0 １0を下の桁で表わしてい る様に思之る。人間の認識論的発達過程から考えると 納得できる様な気がする。

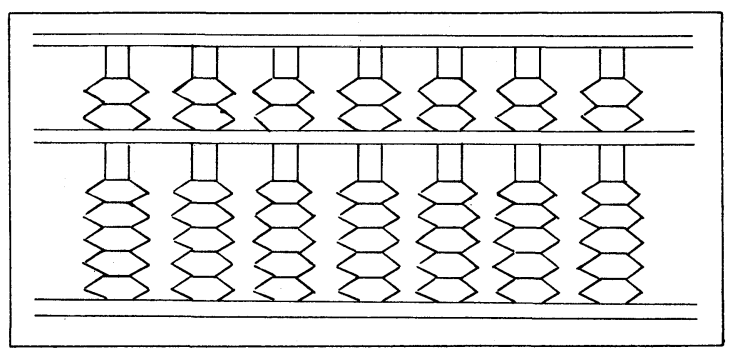

図 1. 昔のソロバン

算盤の様に量の概念を離散的な数として扱う計算機 をデジタル (digital) 計算機という。まさに digital(指 の，指のある，指状の …)という意味を考之れば，おの ずと意味がわかる。デジタル計算機に対してアナログ (analog) 計算機がある。analog, analogue(類似物, 相 似体)とは, ある物理量を電圧, 電流…を用いて量的概 
念を表現して, 算術演算の為に用いられている。代表 的な例として，計算尺をあげることができる。計算尺 の原理は, 乗法式の両辺の対数をとると, 対数法則か ら対数の加法形に変形できるということである。

$$
\begin{aligned}
& \mathrm{Y}=\mathrm{X}_{1} \times \mathrm{X}_{2} \times \mathrm{X}_{3} \cdots \cdots \cdots \text { 乗法形 } \\
& \log \mathrm{Y}=\log \left(\mathrm{X}_{1} \times \mathrm{X}_{2} \times \mathrm{X}_{3}\right)
\end{aligned}
$$

$\log \mathrm{Y}=\log \mathrm{X}_{1}+\log \mathrm{X}_{2}+\log \mathrm{X}_{3} \cdots \cdots$ 加法形

もうひとつアナログ計算機に含めたいものがある。 それは日本の大工さんが使う差金(あるいは曲尺)であ る。差金とは鋼または真鍮で直角に折れ曲った形につ くった物差しであり，誰でも一度は見たことがあるは ずである。どこがアナログ計算機かというと，表に普 通の単位の長さを刻み, 裏には平方根の目盛を刻み, これを裏目といって，正方形の一辺の長さを表目のあ る数だけとると，その対角線の長さが同じ数だけの裏 目でとれる。具体的には丸太の断面の直径を裏目で計 ると，いったい何寸角の柱がとれるかすぐわかるわけ である。(図 2)

差金(曲尺)など，日本には江戸時代からあり，工匠 の必需品となっている。

パソコンも含めて，ほとんどのコンピュータはデジ タル計算機で，アナログ計算機は計測器の制御などに
使われている。おもしろいことに，デジタル時計がし ばらく人気があったが，序々にアナログ時計に人気が もどりつつある。それは，あと何時間あるかとか，あ と何分あるかという時に視覚から受ける量的概念はア ナログの方が理解しやすいからではないかと思える。 アナログとデジタル計算機はそれぞれ特性を持ち，使 用用途によって使いわけられている。

\section{II. 沉用電子情報処理機としてのコンピュータ}

パソコンの基礎的知識というよりも，雑学的な事柄 を書いたが，コンピュータとは彗星のごとく出現した “新物体”ではなく，我々の身近かにあるも市や道具 から産み出されたものであることを理解してもらいた い為である。算盤や，計算尺といったものは，あくま でも計算をする道具といった観がある。そのような意 味で計算をする機械はパスカル (Pascal 1623 1662) やライプニッッ(Leibnitz 1646〜1716)によって考案 された歯車式の卓上計算機であろう。その歯車式計算 機は，あるいは手まわし式計算機と呼ばれ，1920 年ご ろには電動化された。それらと並行して，事務処理の 為に考案されたものに, パンチカードがある。パンチ カードは19世紀にはすでに使用されて，20世紀に なると事務処理の先兵となっていた。(図 3)

1930 年, 数值計算のみとか文字情報の整理などを組 合せた，つまり歯車式計算機とパンチカードシステム

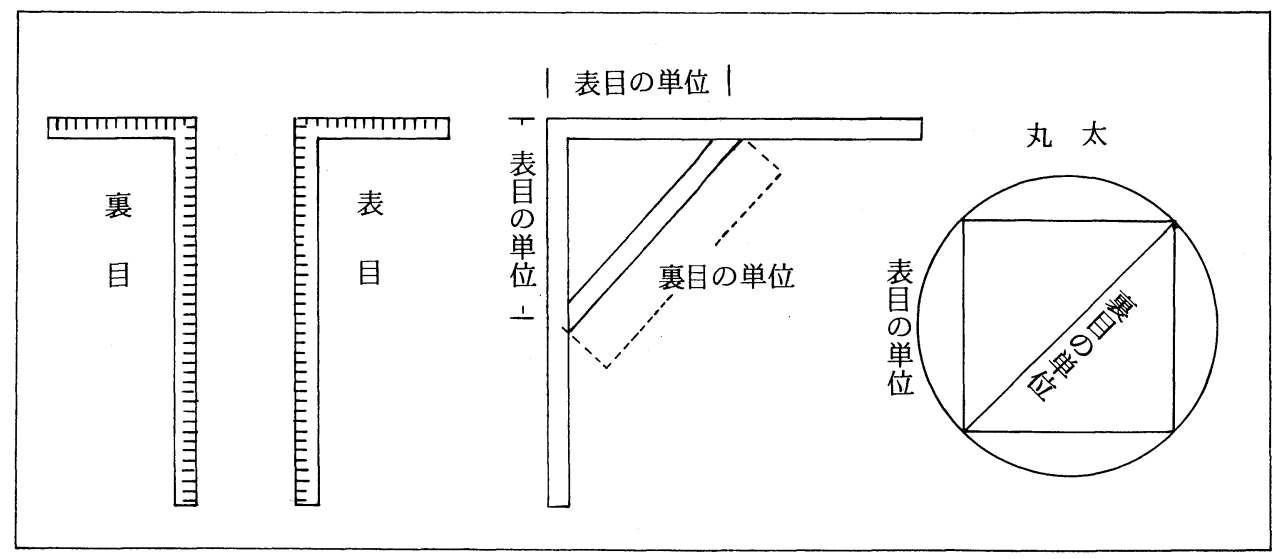

図2.差 金 
を組合せたリレー式計算機が誕生した。リレーとはあ る回路に電流を流すと, 電磁石の原理で他の回路のス イッチ操作をする様な小さな操置である。これが多数 つぎからつぎと作動するとものすごい音がしたと言う ことである。この頃から単なる計算の為の機械といj よりも汎用電気情報処理機といったイメージが生まれ てきた。

1940 年リレーの代りに真空管を用いた電子管式計 算機が作成された。これは計算の速度は画期的であっ たが, 現在のコンピュータの様にあらかじめ入力して あるプログラムに順って計算を実行する機械ではな く，計算手順を外部(多数のスイッ千や結線)からその つど指示しなければならない機械であった。つまり現 在の, プログラム内蔵式でない電卓の様なものと理解 できる。

1945 年ごろになると, 現在のコンピュータの基本と なるプログラム内蔵式計算機 von Neuimann 型計算 機が製作された。EDSACである。von Neuimann型 計算機とは図4のような構造を持っていた。このレべ ルまでが第一世代のコンピュータである。つまり主構 成部品が真空管とリレーで, 大きな部屋と巨大な電力 を必要とし，また安定が非常に悪かったので，計算す るのに, すばやさが必要であった。

1960 年代に入ると, 主構成部品が真空管からトラン ジス夕に代った。第二世代コンピュータの時代である。
さらに集積回路(IC, Integrated Circuit)を用いた第三 世代コンピュータができ, 1970 年代は, 集積密度をさ らに高めた大規模集積回路 (LSI ; Large Integrated Circuit)による第四世代コンピュータと発展して来て, 現在第五世代のコンピュータの開発が真近にせまって いる。

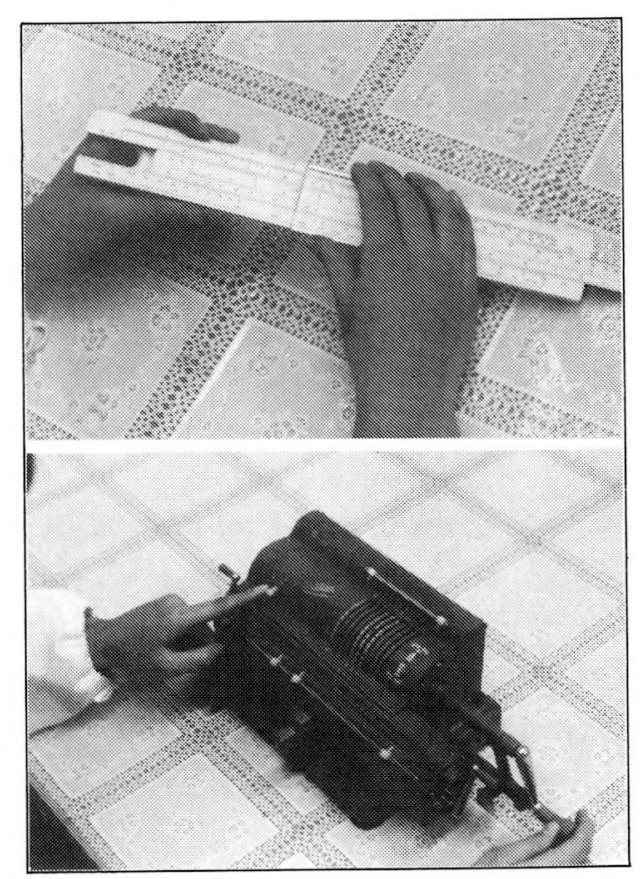

図 3，計算尺，手まわし式計算機

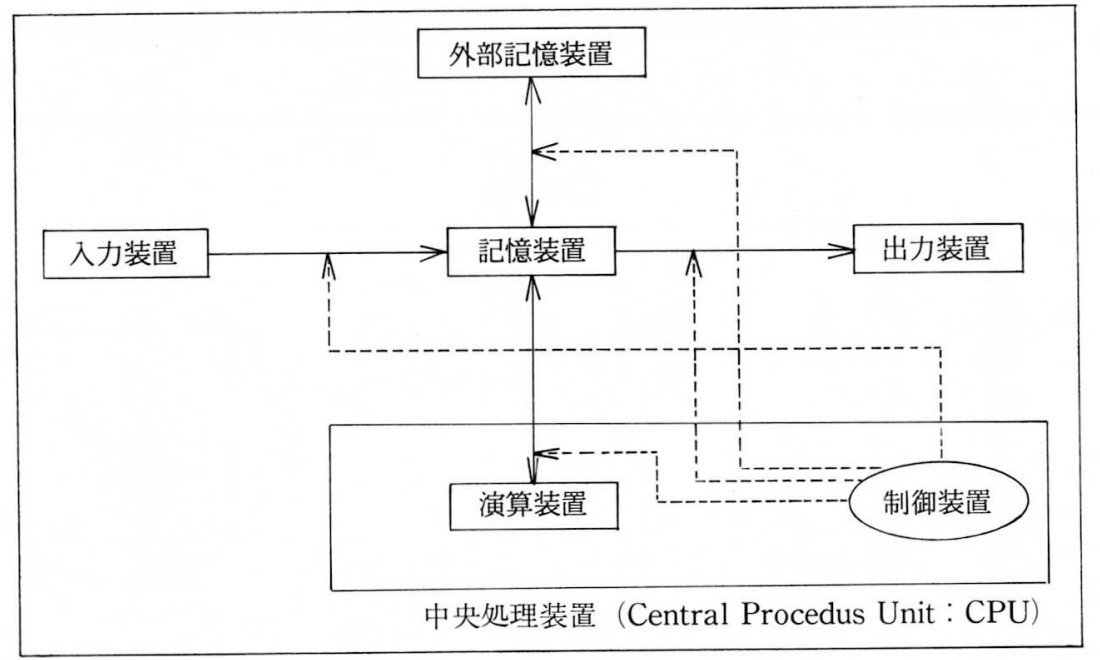

図 4. von Neuimann 型コンピュータシステム 


\section{III.コンピュータの規模と性能}

コンピュータの規模をよく超大型, 大型, 中型, 小 型(ミニコン)，パソコン，ママイコという様な言葉で 区別するが，明確な定義は存在していない様である。 というのもコンピュータの性能は日進月歩の勢いで, 特に演算速度の向上は指数関数的である。パソコンと いえども, 10 年前の中型，小型以上の性能を持つもの が登場している。さらに価格と性能が厳密に比例して いないことが，今のコンピュータがまだ発展途中であ ることを表わしている。

コンピュータの規模の区分を価格によって分けるの も1つの方法であったが，今では電算機の規模を主記 憶装置 (main memory)の大きさで分けるのが一般的 と言える。アルファベットや特種記号 $(*, /,+,-, \cdots)$ などを表現する単位(後述)の 1 バイト (byte)を規準に してコンピュータの規模を区分するものである。

1 バイト $($ byte $)=1$ 文字 (character), 数字

$1,024 \times 1$ byte $=1$ キロバイト $(\mathrm{KB})$

$1,024 \times 1 \mathrm{~KB}=1$ メガバイト $(\mathrm{MB})$

$1,024 \times 1 \mathrm{MB}=1$ キガバイト $(\mathrm{GB})$

また 2 byte で漢字 1 字を表わす。

$\begin{aligned} \text { 超大型機 } & \mathrm{GB}=10 \text { 億バイト } \\ \text { 大型機 } & 10 \sim 100 \mathrm{MB} \\ \text { 中型機 } & \text { 数 } \mathrm{MB} \\ & \\ \text { バソコン } & 64 \mathrm{~KB}, 128 \mathrm{~KB}\end{aligned}$

また数バイトを一組として，処理単位とするものも あり，例之ば， 4 byte=1 wordあるいは, 2 byte= 1 word である。普通スーパーミニコンは， 1 word= 4 byte として, さらに主記憶装置 (main memory) も 4〜16 MBもあるものが出現している。この様にある 程度, 主記憶装置の大きさによってコンピュー夕の規
模が区別できるが，しかし，規模が大きいからといっ て性能が良いとは限らない, 例之ば, 処理がワード単 位か, バイト単位か, とでは処理時間が異なり, さら に中央処理装置が演算速度, 入出力装置や外部記憶装 置とのデー夕転送速度などが影響する。また, 以上述 べたようなハードウェアと同様にソフトウェアの影響 も考慮に入れなければならない。

\section{IV．パソコンとマイコン}

パーソナル・コンピュータとマイクロ・コンピュー 夕などと呼ばれる，身のまわりの事務処理や実験デー 夕の整理などに使われるコンピュータについて多少の 解説をしておく。

ミニコンから超大型計算機, 現在ではスーパー・ミ ニコンピュータが出現しているが，それら全て，その 中央処理装置は IC や LSIの組み合わせによって構成 されている。それらを対比して，中央処理装置を 1 個 のユニットにまとめたものをマイクロ・プロセッサと いう。パソコン, マイコンは, このマイクロプロセッ サを中心に主記憶装置や入出力装置補助記憶装置を組 み合わせて構成されている。特にマイクロ・プロセッ サと主記憶装置からなるものとマイコンという。さら に, それに加えて, 入出力装置や補助記憶装置からな るものをパーソナル・コンピュータと呼ぶ。(図5，図6)

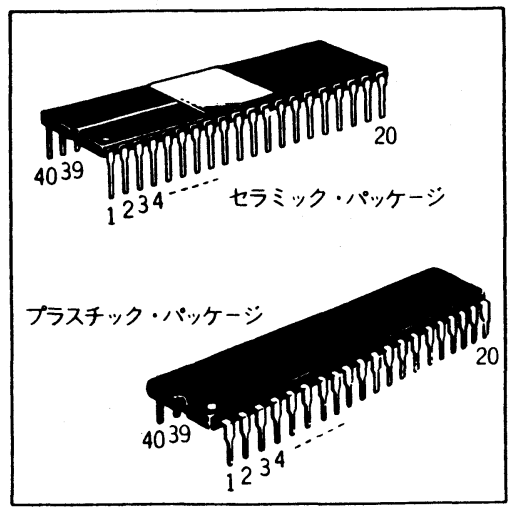

図 5，マイクロ・プロセッサの外観（6809 CPU） 
マイクロ・コンピュータは計測機器やその他の電気 器具の内部に組み込まれて, その機器の効率を最大限 に生かす為の制御に用いられている。我々が実際に事 務処理やワープロの代用等の汎用に用いるものはパー ソナル・コンピュータと呼ばれている。そこで以後, パソコン(パーソナル・コンピュータ)を前述した意味 において，マイコンと区別して扱うことにする。

現在のようなパソコン, マイコンの普及には前述し たマイクロプロセッサの開発が必要であった。1971 年 に米国，インテル社によって開発されたマイクロプロ セッサ 4004 にはじまり，その後 8080 Aの発売によっ てマイコン, パソコン, ブームがはじまった。その後 米国, ザイログ社の Z 80, 16 bit 夕イプである米国, モ トローラ社 68000 などの開発によって, マイクロプロ セッサは不動の地位を築いた。また，その性能は 10 年 前の中型機, 15 年前の大型機に匹敵するという。
V. パーソナル・コンピュータ

パソコンを事務処理, デー夕処理にもちいることに よる利点として，同一な作業を反復的に行なうような 場合，高速かつ誤りなく作業を進めることが出来る。 ただし，それにはプログラム言語を介して使用者であ る人間の意志 (処理内容)を入力しておかなければなら ない。さらに処理内容が変更された場合にプログラム を修正することで対応できる。しかしながら処理すべ き対象が数十, 数百ぐらいであれば人間の処理能力の 方が適格である。また外部記憶装置や補助記憶装置を 付加することによって記録を保存することができ, 後 で直ぐに参照あるいは再処理が可能である点も利点と してあげられる。

(次号に続く)

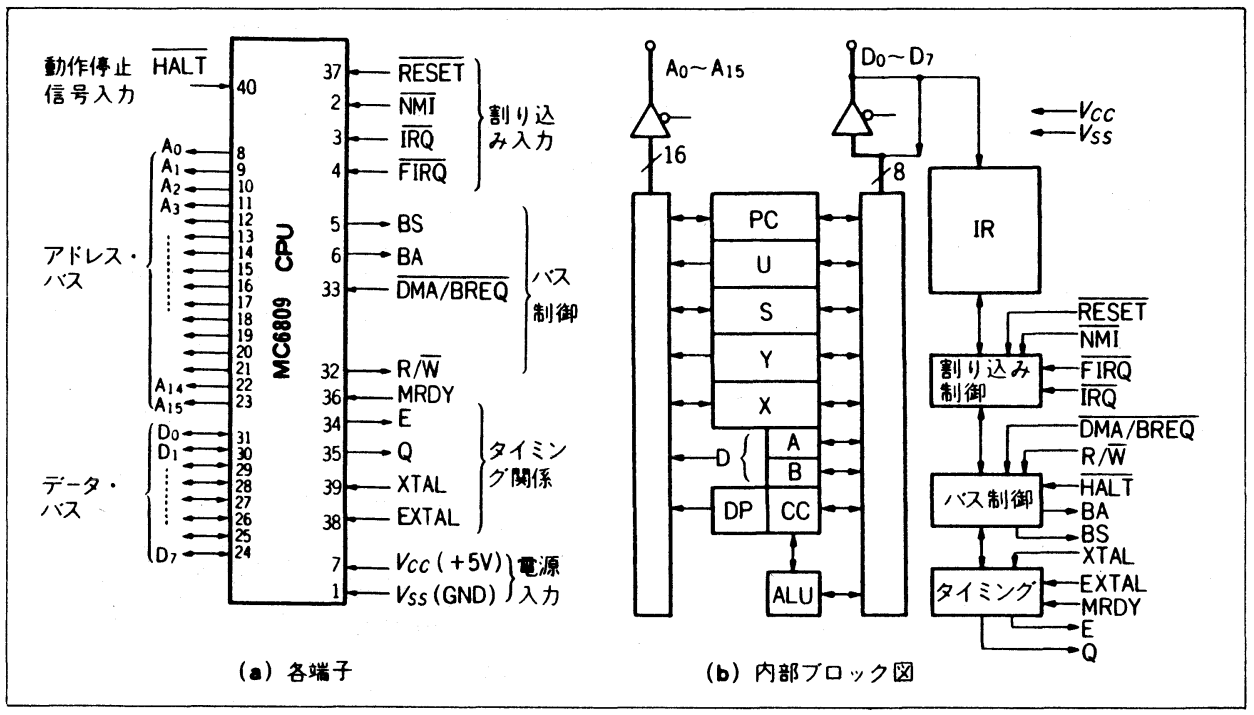

図 6.マイクロ・プロセッサの概略（6809 CPU；モトローラ社資料より） 